\title{
A Study of Commonly Used Design Solutions for Green Roofs in Dhaka City and their Comparative Analysis
}

\author{
Mehreen Hossain ${ }^{1}$, Hassan Mahmud ${ }^{2}$, Sujaul Islam Khan ${ }^{3, *}$ \\ ${ }^{1}$ Shanto-Mariam University of Creative Technology \\ Dhaka, Bangladesh \\ ${ }^{2}$ Department of Environmental Science and Management, North South University \\ Dhaka, Bangladesh \\ ${ }^{3}$ Department of Architecture, North South University \\ Dhaka, Bangladesh \\ *Corresponding author's E-mail: email: sujaul.khan [AT] morthsouth.edu
}

\begin{abstract}
Although architects, landscape designers and building engineers have been designing and building green roofs in Dhaka, Bangladesh, there is a dearth of evidence based research regarding the best practices of setting design parameters, available solution types and performance. Based on the descriptive survey method, this study identifies three basic types of green roofs. The common construction and use related design parameters used by the local practitioners were identified. The three types of green roofs are compared on the basis of their performance against these design parameters. It was concluded that further research, proper policies and research based development in the practice is necessary to materialize the true potential of green roofs and roof top gardening in Dhaka which will address the UN sustainable development goals.
\end{abstract}

Keywords--- Green roof, Rooftop landscape, construction techniques. UN SDG goals

\section{INTRODUCTION:}

Roof top gardens can play a significant role to reduce the urban heat island effect, reduce dependence on storm water drainage systems, improve air quality, reduce air pollution, address recreational needs, supplement food sources and provide manifold ecological benefits in urban areas (Mowla 2010), all of which address the UN sustainable development goals 11,13 and 15. Green roofs have been used for over two decades now in Bangladesh. (Mowla 2010) Architects, engineers have developed a local version of building green roofs with the loading conditions, available materials, construction techniques, and costs, types of plantation, growing medium, drainage and waterproofing systems as the key design parameters in Bangladesh. This paper will also identify and make a comparative analysis of the key types of green roofs used in the capital Dhaka on the basis of the construction and use related design parameters.

\subsection{Objective of the Study}

To fulfill the aim of the study the following specific objectives have been formulated. They are:

1. To identify major types of design solutions used for green roofs in the Dhaka city.

2. To identify major design parameters for these design solutions in the context of our country used by some of the key practitioners.

3. To assess the performance of the different types of green roof design with reference to the design parameters stated in 2.

4. To devise a set of recommendations to enhance the possibilities of green roofs in the urban areas on the basis of the performance assessment.

\subsection{Approach}

The descriptive survey method has been considered as appropriate to this study since it aims to describe the present condition of green roof design practices in Dhaka and assess their performance. The research was done basically in four phases, which are -

1. A literature survey was done to gain the necessary knowledge of contemporary practices and parameters of green roof design in developed countries, and the prospects and potentials of green roofs in Bangladesh. 
2. Primary information was gathered through key informant interview and Focus Group Discussion. (18 respondents and participants including Architects, civil engineers, garden owners, landscapers and nursery owners with 18-20 years of experience in the field)

3. The primary information has been verified through field survey and case observation.(Physical survey of 24 buildings with roof top gardens)

4. Finally different tools of analysis were developed and applied as suitable to evaluate the performance of the roof gardens against various design parameters.

\subsection{Methodology for type identification:}

To identify the basic types of green roof design solution the construction technique and materials used has been considered as the primary criteria for classification. For the purpose key informants and participants in the field such as architects, civil engineers, garden owners, landscapists and nursery employees with long experience regarding roof gardens were interviewed.

\subsection{Methodology for comparative analysis:}

From the literature review it has been found that some issues are considered globally when green roof projects are undertaken (Weiler and Barth, 2009). These are: i) Structural load. ii) Efficiency of drainage and damp protection. iii)Installation. iv) Maintenance

To compare structural load imposed by each type of garden weight of commonly used materials were used based on data from Bangladesh National Building Code (2014), Weiler and Barth (2009) and field measurements.

\subsection{Limitations}

The research was done with limited resources within a short timeframe. So the sample size of roof gardens for survey is not large. Interviews with architects, landscape designers, nursery authorities and garden owners were the key source of information. The study focuses only on the construction and design part of roof gardens.

\section{IDENTIFICATION OF DESIGN SOLUTION TYPES FOR GREEN ROOFS COMMONLY USED IN DHAKA}

From the field studies and interviews with architects and landscape professionals, three broad types of currently used solutions were found on the basis of the differences in approaches to solving the issues mentioned above in 1.4. It was also seen that the three types can be used in a combined manner. The height of the soil varies between 100 to1200 mm. The types are: i)Type 1 of Green Roof: Isolated Slab System ii) Type 2 of Green Roof: Continuous system with filtrationsystem. iii) Type 3 of Green Roof: Continuous system without filtration system The following sections explains these design details and their attributes.

\subsection{Type 1 of Green Roof: Isolated Slab System:}

Separate precast RC slabs of around 600-900mm width and minimum 50mm thickness are placed with an air gap of minimum 50mm from the main RC roof. A patent stone roof is cast on the main RC roof to ensure slope for drainage of the main roof as shown in Figure 1 (Khan, S. Interviewed 2017). Usually there are gutters or channels kept around the raised roof to drain the surface runoff of the main roof surface. These gutters and channels are connected with the main storm drainage system of the building. The soil layer must have separate systems of pipes to drain out excess water to such gutters or onto the main roof surface. To avoid clogging of the pipes by soil the mouth of the pipe is usually protected by wire mesh or gravel filtration system and/or drainage system within the elevated slab below the soil layer as described in Type 2 design detail.

Figure 2 shows the plans and view after completion of roof garden at annex building of South Breeze School using Type 1 design detail. Here any filtration or drainage layer is not used under soil as the area of the bed is small. Figure 3 and 4 shows two other examples of its use. 


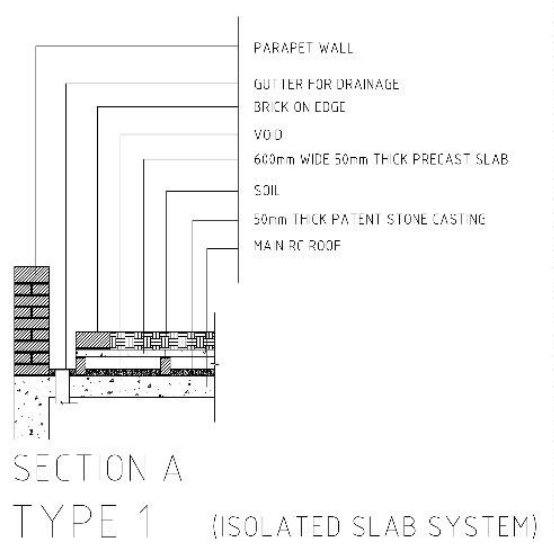

Figure 1: Sectional drawing of Type 1 Isolated Slab system

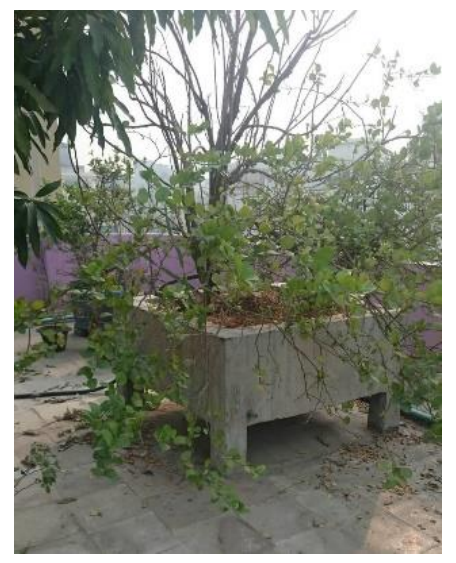

Figure 3: Small bed is built for single large plants using design detail 1
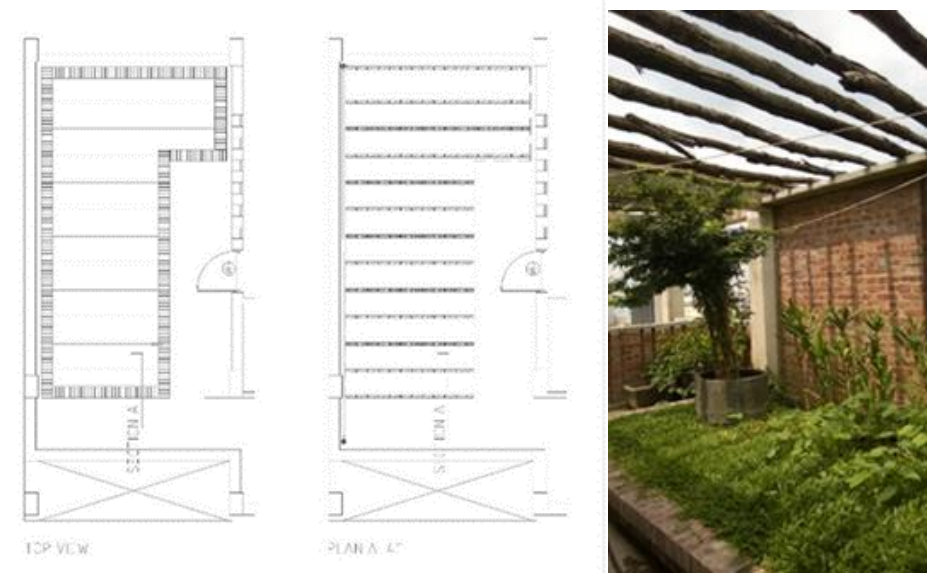

Figure 2: Plan and photo of type 1 Isolated Slab System. Project: South Breeze School Annex building, Uttara, Dhaka

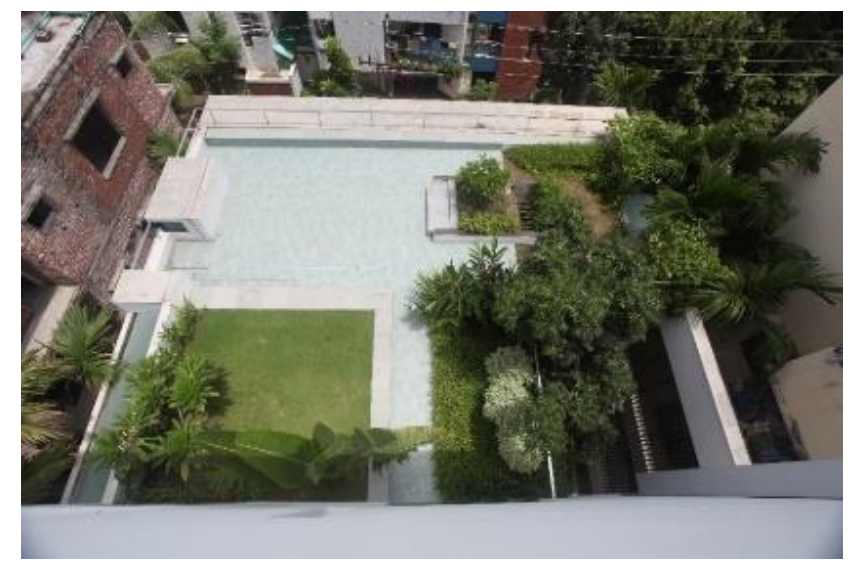

Figure4: Roof garden at Malek residence at Gulshan by DWM4 architects using design detail

\subsection{Type 2 of Green Roof: Continuous System with filtration:}

This system uses a liquid, self-adhesive or cold applied water proofing membrane placed over the main RC roof. (Refer to Fig 5,6,7 \&8). A patent concrete casting is laid over the membrane. A layer of $12 \mathrm{~mm}$ downsize gravel is placed over the patent concrete casting. A geotextile membrane is placed over this layer of gravel. A 25-50 mm thick layer of sand is used as an alternate of geotextile. Earlier when geotextile was not in the market this was a common solution. Finally the growing medium, usually soil, is placed on top this layer.

Properly designed plumbing system must be installed to ensure effective drainage of both surface run off and excess water in the soil. This is usually through a system of pipes that take the excess water from the bottom layer of the beds to the main storm water drainage system of the roof. Figure 7 and 8 shows examples of its use in two different gardens using pits and gutters for drainage water release.

Survey showed that $85 \%$ of the practitioners prefer to use more than one layer of chemicals or other water proofing layers to fool-proof the damp proofing systems. This is due to the fact that the quality of materials and construction is often hard to maintain. It is of critical importance that the roof garden is designed and executed by a team of experienced professional architects, landscaping professionals and plumbing engineers. According to the $75 \%$ of designers, this system is very dependable when constructed according to design and specifications. The structural load of the additional slab used in Type 1 is reduced. The practitioners have stated that when done with proper care, this system becomes almost maintenance free. Inspections are required twice a year. (Chowdhury M. Interviewed 2017) 
Figure 9 and 10 shows the use of multiple layers of waterproofing membrane by Architect Rafiq Azam Principal, Shatotto architects, and Architect Selim Altaf, Director, Synthesis Architects. (Altaf, S, Interviewed 2017. Azam, R Interviewed on 08062017)

\subsection{Type 3 of Green Roof: Continuous system without filtration:}

This system is similar to type 2, but gravel and geotextiles are not used to ensure proper filtration and drainage of the excess water in the soil or other growing medium. (Refer Fig. 11. $12 \& 13$ ) This short coming may be overcome by taking the necessary steps ensuring that the drainage pipes do not become clogged with the particles of soil. This design is less popular among designers and often done at rudimentary level by garden owners by themselves using different types of water proofing layers. It is mostly used for smaller size beds. In case of larger soil depths the bed may be provided with drainage pipes without filtration or with minimal filtration. For shallow soil depth drainage pit with gratings protected by gravel or coconut fibers may be enough. Here pipes are used to drain out the water from the bottom of the beds without filtration.

Figure 13 shows use of similar design detail at artist Saidur Rahman's house with 300-450 mm soil depth using panaflex (a type of PVC) sheets for water proofing with an extra layer of patent stone for protection.

\section{COMPARATIVE ANALYSIS OF DESIGN SOLUTION TYPES FOR ROOF GARDENS}

\subsection{Criteria for comparative assessment}

The criteria for comparative assessment are these following four issues:

i) Structural load. ii) Efficiency of drainage and damp protection. iii) Installation. iv) Maintenance

\subsubsection{Structural load}

\section{Load calculation issues and codes}

For green roof type design solutions minimum thickness for all layers is considered with soil depth of $150 \mathrm{~mm}$ (minimum soil depth used for plantation in Dhaka) to get the minimum amount load imposed by each of the design types. Bangladesh National Building Codes (BNBC) specifies loads to be considered for different materials for structural design in the country. These information are used to find the extra structural loads of the roof garden.

According to BNBC (2014) minimum loads for rooftop gardens: From section 2.3.8.2 Special Purpose roofs: For Special Purpose roofs, live loads shall be estimated based on the actual weight depending on the type of use but shall not be less than the following values: Roofs used for Gardens- $5 \mathrm{kN} / \mathrm{m}^{2}$. From Section 2.3.10 Partial loading and other Loading Arrangements, Table 2.3.2, Minimum Roof Live Loads, the minimum Distributed Load for a flat roof is $1.5 \mathrm{kN} / \mathrm{m}^{2}$.

Weiler and Barth (2009) combine various codes used in the USA such as the ASTM, ACI and the International Building Code. They also have compiled the typical weights of soils used in Table 2. This table also shows the unit weight for materials according to the Bangladesh National Building Code (BNBC) 2014 and actual measurements taken from field survey. 


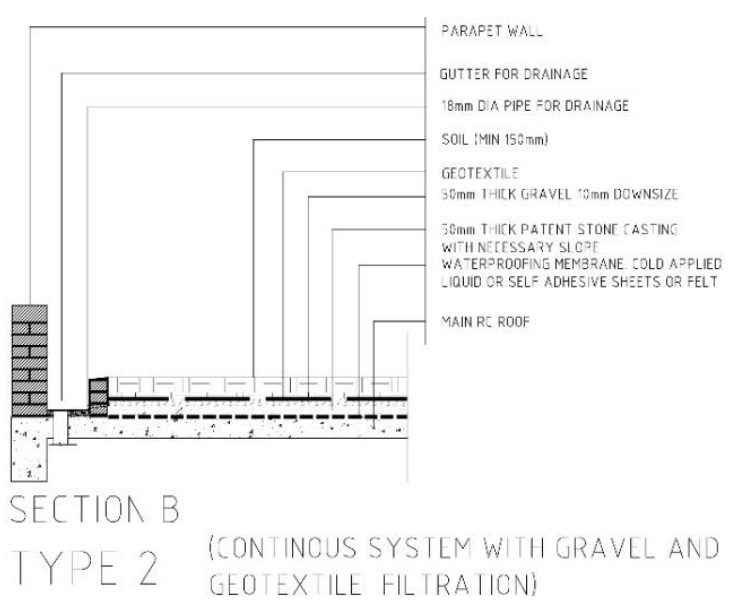

Figure 5: Sectional Drawing of a type 2 Continuous system with Gravel and Geotextile Drainage system

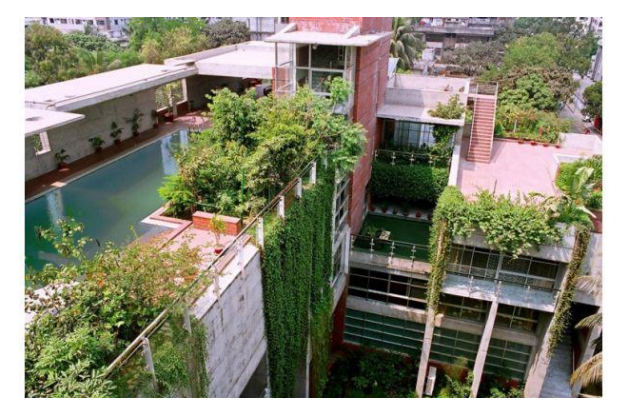

Figure 7: Roof garden of Meghna residence by Ar. Rafiq Azam using design detail type 2 green roof

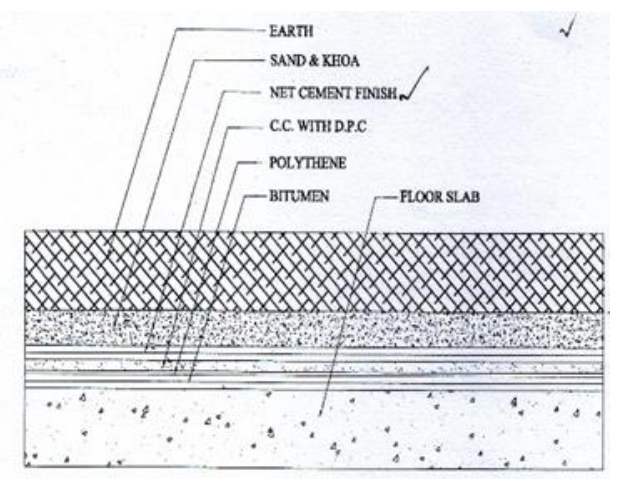

Figure 9: Section drawings of a Type 2 Continuous system with filtration system Source: Shatotto Architects

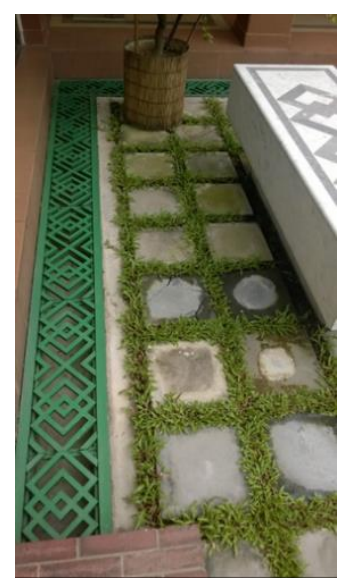

Figure 6: Peripheral gutter in the roof garden of Jamatkhana, Bashundhora R/A using design detail type 2 green roof

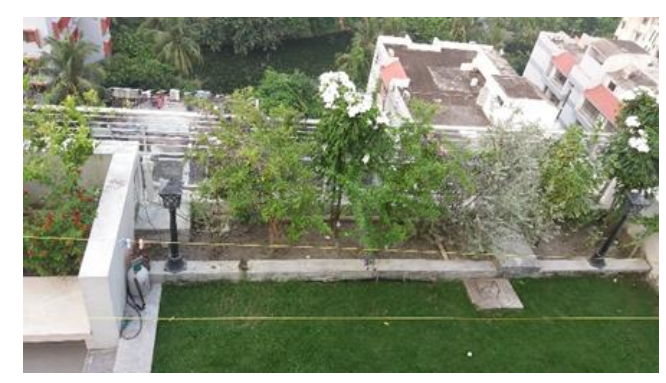

Figure 8: Roof garden showing drainage pit at Manama Shondha Apartments by Ar. Selim Altaf using design detail type 2

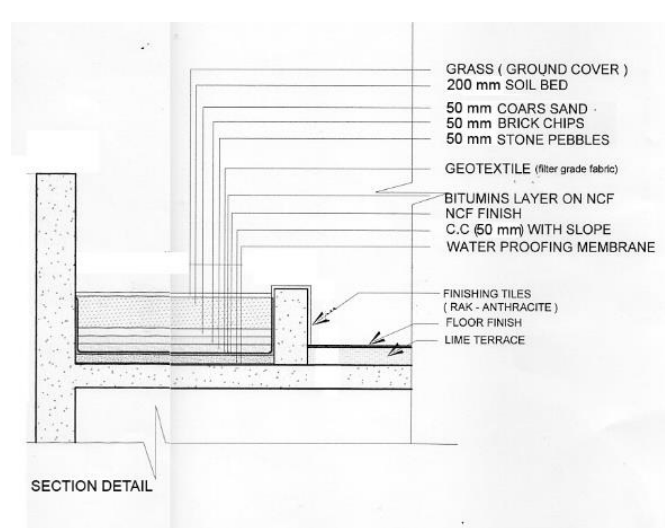

Figure 10: Section drawings of a Type 2 Continuous system with filtration system Source: DWM4 Architects 


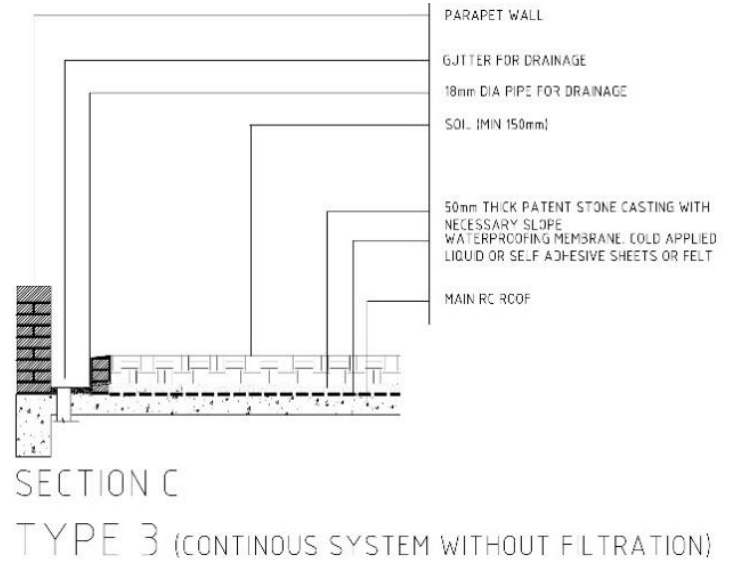

Figure 11: Sectional Drawing of Type 3 Continuous System without Filtration.

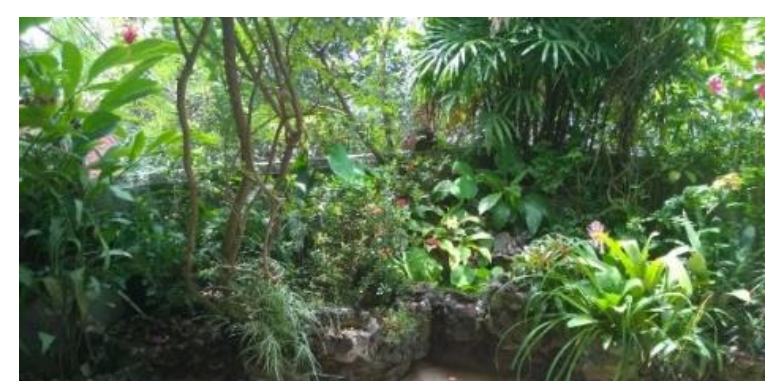

Figure 13: Roof garden at Artist Saidur Rahman's house using Design detail type 3 green roof

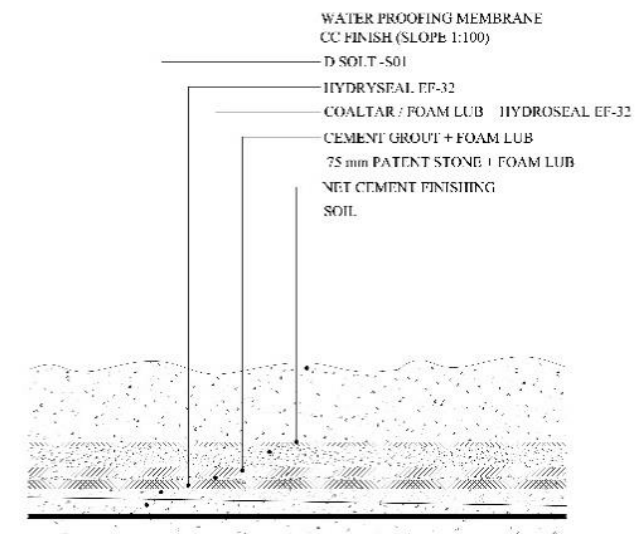

Figure 12: Section drawings of a Type 3 Continuous system without filtration system Source: Synthesis Architects

Table 2: Weight of common materials used in the Green roofs. Source as shown

\begin{tabular}{|c|c|c|c|c|}
\hline \multirow[b]{2}{*}{ SI } & \multirow[b]{2}{*}{ Name of material } & \multicolumn{3}{|c|}{ Density per unit in $\mathrm{kg} / \mathrm{m}^{3}$ with source } \\
\hline & & Field Survey & $\begin{array}{l}\text { Barth } \quad \& \\
\text { Wieler }\end{array}$ & BNBC 2014 \\
\hline 1. & $\begin{array}{l}\text { Standard soil mix (medium moisture/water) } \\
\text { Standard soil mix (saturated moisture/water) }\end{array}$ & $\begin{array}{l}1601.85 \\
1762.03\end{array}$ & $\begin{array}{l}1681.94 \\
1922.22\end{array}$ & \\
\hline 2. & Coarse Stone chips & & 1681.94 & \\
\hline 3. & Brick Chips & 1762.03 & & \\
\hline 4. & Fine Sand & 1922.22 & & 1601.85 \\
\hline 5. & Coarse Sand & & & 1665.92 \\
\hline 6. & Coco Peat Growing Media & 576.66 & & \\
\hline 7. & $\begin{array}{l}\text { Weight of Concrete (brick aggregates) } \\
\text { Weight of Concrete (stone aggregates) }\end{array}$ & & & $\begin{array}{l}2306.66 \\
2082.40\end{array}$ \\
\hline 8. & Weight of Patent Stone Concrete casting & & & 1681.94 \\
\hline 9. & Weight of Bricks, and pavers & & 1922.22 & \\
\hline 10. & Weight of Water & & 1001.15 & \\
\hline
\end{tabular}


Table 3: Comparison among roof garden design type regarding structural load

\begin{tabular}{|c|c|c|c|c|}
\hline $\begin{array}{l}\text { Sl. } \\
\text { N } \\
\text { o. }\end{array}$ & $\begin{array}{l}\text { Design } \\
\text { Type }\end{array}$ & Methodology & $\begin{array}{l}\text { Load } \\
\text { Imposed } \\
\mathrm{kN} / \mathbf{m}^{2}\end{array}$ & Remark \\
\hline 1. & $\begin{array}{l}\text { Type } 1 \text { of } \\
\text { Green Roof }\end{array}$ & $\begin{array}{l}750 \mathrm{~mm} \text { x } 3050 \mathrm{~mm} \times 60 \mathrm{~mm}(\mathrm{WxLxD}) \\
\text { precast concrete slabs were placed on } 5 \text { " } \\
\text { wide brick walls. Depth of soil was } 150 \\
\mathrm{~mm}\end{array}$ & 4.45 & $\begin{array}{l}\text { The size and shapes of the beds may } \\
\text { vary considerably. In some cases the } \\
\text { spacing of the supports and thickness } \\
\text { of the concrete slabs vary. }\end{array}$ \\
\hline 2. & $\begin{array}{l}\text { Type } 2 \text { of } \\
\text { Green Roof }\end{array}$ & $\begin{array}{l}50 \mathrm{~mm} \text { thick Patent stone casting was } \\
\text { considered as floor finish. Geotextiles, a } \\
2 \text { " thick layer of gravel and } 150 \mathrm{~mm} \\
\text { thick layer of soil was used. }\end{array}$ & 3.54 & $\begin{array}{l}\text { The depth of the soil will change if } \\
\text { larger trees are planted. }\end{array}$ \\
\hline $\begin{array}{l}3 \\
.\end{array}$ & $\begin{array}{l}\text { Type } 3 \text { of } \\
\text { Green Roof }\end{array}$ & $\begin{array}{l}50 \mathrm{~mm} \text { thick Patent stone casting was } \\
\text { considered as floor finish. } 150 \mathrm{~mm} \text { thick } \\
\text { layer of soil was used. }\end{array}$ & 2.63 & $\begin{array}{l}\text { The depth of the soil will change if } \\
\text { larger trees are planted. }\end{array}$ \\
\hline
\end{tabular}

With this information, an approximate calculation for the additional loads for the green roof has been made. Patent stone finish has been regarded as the floor finish. To ensure better structural load distribution and safety, expert structural engineers prefer to place the heavier components and areas closer to or above the beams/girders. It is also necessary to ensure that the structural systems and load calculations are done at the preliminary stage of the design as all structural loads influence the foundations. (Alam S Interviewed on 05062017, Ahmed S Interviewed on 06062017, Nurul Amin Interviewed on 06062017)

\subsubsection{Efficiency of drainage and damp protection}

Success of roof garden design solution primarily depends on its efficiency in protecting the building from the water and moisture contained in the soil or growing medium of the garden. Proper drainage of the excess water from the soil and protection of the roof surface against dampness has to be there. (Refer to Table 4).

Table 4: Comparison among roof garden design types regarding efficiency of drainage and damp protection

\begin{tabular}{|c|c|c|c|}
\hline Type & $\begin{array}{l}\text { Drainage of surface run off and excess } \\
\text { water in growing medium layer }\end{array}$ & $\begin{array}{l}\text { Waterproofing and } \\
\text { Moisture control of } \\
\text { main slab. }\end{array}$ & Preferred application \\
\hline $\begin{array}{l}\text { 1.Type } 1 \text { of green } \\
\text { roof : Isolated Slab } \\
\text { System }\end{array}$ & $\begin{array}{l}\text {-Storm water and excess water in the } \\
\text { beds must be allowed to drain } \\
\text { underneath the raised slabs. } \\
\text {-Provisions are kept to allow the excess } \\
\text { water to drain from the beds with } \\
\text { separate pipes. } \\
\text {-Generally, the main storm water } \\
\text { drainage system of the roof is used. }\end{array}$ & $\begin{array}{l}\text {-The isolated slab system } \\
\text { is designed to prevent } \\
\text { moisture from } \\
\text { penetrating the main roof } \\
\text { slab by using a separate } \\
\text { slab with a gap in } \\
\text { between. }\end{array}$ & $\begin{array}{l}\text {-Preferable in both old } \\
\text { and new buildings } \\
\text { from the view of } \\
\text { drainage and moisture } \\
\text { control. } \\
\text {-Not suitable for large } \\
\text { gardens. }\end{array}$ \\
\hline $\begin{array}{l}\text { 2.Type } 2 \text { of green } \\
\text { roof: Continuous } \\
\text { system with } \\
\text { filtration }\end{array}$ & $\begin{array}{l}\text {-The drainage system includes an } \\
\text { elaborate filtration system by geotextile } \\
\text { or sand with a layer of gravel underneath } \\
\text { the growing medium. } \\
\text {-Surface run off is also collected with } \\
\text { gutters and drains at the top surface. } \\
\text {-This system has to be connected to the } \\
\text { building's plumbing system by pipes } \\
\text { through peripheral gutter or pits. }\end{array}$ & $\begin{array}{l}\text {-Penetration of moisture } \\
\text { and dampness from the } \\
\text { green roof the main slab } \\
\text { depends on the quality of } \\
\text { construction and } \\
\text { materials used for } \\
\text { waterproofing and also } \\
\text { the drainage system. }\end{array}$ & $\begin{array}{l}\text {-Suitable for larger } \\
\text { areas. Depth of the } \\
\text { growing medium can } \\
\text { be more than } 200 \mathrm{~mm} \text {. }\end{array}$ \\
\hline $\begin{array}{l}\text { 3.Type } 3 \text { of green } \\
\text { roof: Continuous } \\
\text { system without } \\
\text { filtration }\end{array}$ & $\begin{array}{l}\text {-This system uses a drainage system for } \\
\text { surface drainage. } \\
\text {-The growing medium is drained directly } \\
\text { without the use of the gravel, sand and } \\
\text { geotextile layer. }\end{array}$ & $\begin{array}{l}\text {-This system depends on } \\
\text { the effectiveness of the } \\
\text { waterproofing layer to } \\
\text { prevent the moisture } \\
\text { penetration to the main } \\
\text { slab and also the } \\
\text { drainage system. }\end{array}$ & $\begin{array}{l}\text {-This system is not } \\
\text { recommended for use } \\
\text { for larger areas or } \\
\text { green roofs where the } \\
\text { depth of the growing } \\
\text { medium is more than } \\
150 \mathrm{~mm} \text {. }\end{array}$ \\
\hline
\end{tabular}




\subsubsection{Installation}

Installation method is different for different design details and has their advantages and disadvantages in the process. (Refer to Table 5).

\subsubsection{Maintenance}

All green roofs need regular maintenance of watering, weeding, inspection for bugs etc. According to their design detail the garden structure requires some maintenance too (Refer to Table 6).

Table 5: Comparison among roof garden design types regarding installation technique

\begin{tabular}{|c|c|c|}
\hline Type & Installation /Construction System & $\begin{array}{l}\text { Remarks on } \\
\text { construction/desion }\end{array}$ \\
\hline $\begin{array}{l}\text { Type } 1 \text { of green } \\
\text { roof: Isolated } \\
\text { Slab System }\end{array}$ & $\begin{array}{l}\text { After the patent stone casting is done, the brickwork is done. } \\
\text { This is followed by the installation of precast concrete slabs. }\end{array}$ & $\begin{array}{l}\text {-Can be constructed by } \\
\text { skilled workmen on the } \\
\text { basis of details and } \\
\text { drawings. } \\
\text {-Loads and drainage } \\
\text { systems must be designed } \\
\text { by professional engineers }\end{array}$ \\
\hline $\begin{array}{l}\text { Type } 2 \text { of green } \\
\text { roof: } \\
\text { Continuous } \\
\text { system with } \\
\text { filtration system }\end{array}$ & $\begin{array}{l}\text {-Construction must be carefully designed and executed. } \\
\text {-A patent stone casting is done over the main concrete roof } \\
\text { slab. } \\
\text {-Water proofing is applied on this Layer. } \\
\text {-Another layer of patent stone casting is done on this layer } \\
\text { after carefully ensuring drainage slopes and waste water } \\
\text { systems. } \\
\text {-Bituminous felt is commonly used in Dhaka. } \\
\text {-Irrigation systems may also be used. } \\
\text {-A layer of gravel, geotextile, and growing medium is } \\
\text { applied on the patent stone casting. }\end{array}$ & $\begin{array}{l}\text {-The entire design and } \\
\text { construction requires } \\
\text { proper engagement of } \\
\text { technical professionals. } \\
\text {-Quality control of the } \\
\text { construction materials and } \\
\text { processes must be } \\
\text { ensured. }\end{array}$ \\
\hline $\begin{array}{l}\text { 3. } \\
\text { rype } 3 \text { of green } \\
\text { Continuous } \\
\text { system without } \\
\text { filtration system }\end{array}$ & $\begin{array}{l}\text {-This system is similar to type } 2 \text {, except that gravel and } \\
\text { geotextiles are not used. }\end{array}$ & $\begin{array}{l}\text {-As in type } 2 \text {, this type } \\
\text { requires installation by } \\
\text { skilled professionals }\end{array}$ \\
\hline
\end{tabular}

Table 6: Comparison among roof garden design types regarding maintenance

\begin{tabular}{|c|c|}
\hline Type & Maintenance \\
\hline $\begin{array}{l}\text { 1. Type } 1 \text { of green roof: Isolated } \\
\text { Slab System }\end{array}$ & $\begin{array}{l}\text {-Overall system requires periodical maintenance. } \\
\text {-It may be maintained by semi skilled workers. }\end{array}$ \\
\hline $\begin{array}{l}\text { Type } 2 \text { of green roof: } \\
\text { Continuous system with } \\
\text { filtration system }\end{array}$ & $\begin{array}{l}\text {-The overall system requires a periodical maintenance done by } \\
\text { professional personnel. }\end{array}$ \\
\hline $\begin{array}{l}\text { 3. Type } 3 \text { of green roof: } \\
\text { Continuous system without } \\
\text { filtration system }\end{array}$ & $\begin{array}{l}\text {-The overall system requires a periodical maintenance done by } \\
\text { professional personnel. }\end{array}$ \\
\hline
\end{tabular}

\section{CONCLUSION AND RECOMMENDATIONS}

Green roofs can be categorized as Type 1 green roof or isolated slab system, Type 2 green roof or continuous system with filtration and Type 3 green roof or continuous system without filtration. A comparative analysis was done of the four local design solutions based on the basic design parameters identified as structural load, efficiency of drainage and damp protection, installation, maintenance, cost and thermal performance. The key findings of the comparative analysis were:

a) Structural Load: Among the various components used, the weight of the soil used as a growing media is the heaviest. $\left(1922.22-2082.40 \mathrm{~kg} / \mathrm{m}^{3}\right)$. Lightweight growing media is now available. The 
weight of such media can be $1 / 3^{\text {rd }}$ of soil. Among the green roofs, the Type 3 green roof is the lightest with only the weight of soil as the major component of the load. Among the four types the Type 1 has the highest structural load.

b) Efficiency of drainage and damp protection: Type 1 green roof performs best. Type 2 and Type 3 require a higher degree of quality control of waterproofing materials and construction.

c) Installation and maintenance: Installation and maintenance of container gardens and Type 1 green roof is comparatively easy and does not require specialized skill. Type 2 and 3 green roof require care and attention of skilled personnel during construction and quality of the water proofing materials. This quality control of products and technicians require skilled management.

d) Further notes from literature survey: There is a knowledge gap regarding the potential of extensive green roof systems and other widely practiced methods and materials of developed countries in the context of Bangladesh. There is a lack of knowledge about the waterproofing technology and structural loads of intensive green roofs among the general public. Partly due to this knowledge gap, conventional container garden type is the most common solution.

It may be inferred that this research will aid the practice of designing and installing green roofs in Dhaka and as well as elsewhere in the country. The findings and further research initiatives in this field will support the country to address the Sustainable Development Goals 11 (Sustainable Cities and Communities), 13 (Climate Action) and 15 (Life on Land).

\section{REFERENCES}

Ansel, W. \& App, R.. Green Roof Policies - An International Review of Current Practices and Future Trends Retrieved on 20052017 from http://www.igraworld.com/links_and_downloads/images_dynamic/Green-Roof-Policies-IGRA.pdf

Asad, K. \& Farzana, F. \& Roy M R 2015 Greening and Roof Top Gardening: Scope and Opportunities in Bangladesh. Retrieved on 0505217 from http://gobeshona.net/wp-content/uploads/2015/01/Urban-Greening-and-Roof-Top-GardeningScope-and-Opportunities-in-Bangladesh.pdf

Berghage, R., D. Beattie, A. Jarrett, C. Thurig, F. Razaei, T. O'Connor. 2009. Green Roofs for Stormwater Runoff Control. U.S. Environmental Protection Agency, Washington, D.C., EPA/600/R-09/026.

Climate Protection Partnership Division 2014 Reducing Urban Heat Islands: Compendium of Strategies. Office of Atmospheric Program U.S. Environmental Protection Agency

Retrieved on 15062017 from https://www.epa.gov/sites/production/files/2014-greenroofscompendium_ch3.pdf

Dunnett NP Kingsbury N. 2004. Planting Green Roofs and Living Walls. Portland (OR) Timber Press.

Erica O., Jeremy L., Brad B., Reid R. C. , Hitesh D., Nigel D., Stuart G., Manfred K.Karen K. Y. Liu, B. R.. Green Roofs as Urban Ecosystems: Ecological Structures, Functions, and Services. BioScience, Volume 57, Issue 10, 1 November 2007. Retrieved 20072017 from https://doi.org/10.1641/8571005

Frazer L. 2005. Paving paradise. Environmental Health Perspectives. 113: 457-462. Google Scholar

German, E and Pyne S. Dhaka: fastest growing megacity in the world: Retrieved on 20052017 from https://www.pri.org/stories/2010-09-08/dhaka-fastest-growing-megacity-world.html

Housing \& Building Research Institute 2014. Bangladesh National Building Code Draft. Government of Bangladesh

Luckett, K., 2009, Green Roof Construction and Maintenance, Green Source

Mowla, Q. A. 2010 Green Roof Concept for Eco-Sustainability in the Context of Urban Dhaka. International seminar on 'GO GREEN; the Architecture of the New Order' ARCASIA, ACA-14 October 25-30, 2010 at Lahore, Pakistan. 2010 Retrieved on 22052017 https://www.academia.edu/6084128/

Green_Roof_Concept_for_Eco-Sustainability_in_the_Context_of_Urban_Dhaka

Sutton, Richard K. (2015) Green Roof Ecosystems, Springer

Ministry of Public Works and Housing: Schedule of Rates for Civil Works Fourteenth Edition: 2013. Government of Bangladesh

Weiler, K. \& Barth, K.S. 2009 Green Roof Systems A Guide to the Planning, Design, and Construction of Landscapes over Structure John Wiley \& Sons, Inc. 